\title{
遠心成形コンクリート充填鋼管柱の耐力・変形性能 ULTIMATE STRENGTH AND DEFORMATION CAPACITY OF CENTRIFUGAL CONCRETE FILLED STEEL TUBULAR COLUMNS
}

\author{
宮木 聡*, 松井千秋**, 畑戸龍夫***, 今村輝 武*** \\ 吉野 茂***, 中克已*** \\ Satoshi MIYAKI, Chiaki MATSUI, Tatsuo HATATO, Terutake IMAMURA, \\ Shigeru YOSHINO and Katsumi NAKA
}

\begin{abstract}
This paper reports bending shear test result of centrifugal concrete filled steel tubular column using super high strength concrete. The concrete is cast by cenrifugal spining method using super high strength concrete, and the concrete portion has a vacant hole. The evaluation formula of compression strength of consideration for confining effect derived from the results of axial compression test by authors. In this paper, the bending shear test under axial force of the column specimens were caried out in order that we may confirm relation between a vacant hole and structual performance. We proposed ultimate bending strength of consideration for confining effect of concrete filled steel tubular column can be estimated by proposed formula.
\end{abstract}

Keywords. centrifugal cast, vacant hole, high strength concrete, concrete filled steel tube, flexure and shear experiments, superposed strength, confining effect, deformation capacity 遠心成形, 空洞, 高強度コンクリート,コンクリート充填鋼管柱, 曲げせん断実験, 一般化累加強度, 拘束効果, 曲げ变形性能

\section{1. はじめに}

遠心成形コンクリート充填鋼管柱 (Centrifugal Cast Composite Column: CCC 柱 ) は，製作工場でコンクリートを遠心成形機によっ て締め固めるため, コンクリートの高強度化と部材のプレキャスト による施工の省力化がはかれる構造柱である。また製作上の特徵と してコンクリート内部に空洞ができるが，筆者ら ${ }^{11}$ は空洞部へのモ ルタル充填の省力化と部材の軽量化を考え, 空洞があるままで実用 化することを提案した。

コンクリート内部に空洞部を有する遠心成形コンクリート充填䤡 管柱の実用化を目的として，筆者ら”は空洞部の大きさを主要な実 験变数とした遠心成形コンクリート充填鋼管短柱の中心圧維実験を 行い，空洞部の大きさが柱の最大耐力・弾塑性性状なぞの基礎的性 状に及ぼす影響を把握した。その実験結果によれば遠心成形コンク リート充填鎆管柱は，鎆管の拘束効果によりコンクリートの耐力上 昇が期待できることが判った。さらに筆者ら ${ }^{2) ３)}$ は中心圧縮実験 の実験結果に基づき, 拘束効果を考慮した軸圧縮酎力式を作成し, 軸圧縮を受ける柱の軸圧縮耐力を精度よく予測できることを示した。

一方，コンクリートを遠心成形によって締め固め，コンクリート 内部に空洞部を有するコンクリート充填鋼管柱の曲げせん断実験を 行った既往の研究では, 空洞部にモルタルを充填して中実断面とし
たもの ${ }^{4)}$ と空洞部の大きさを一定としたもの ${ }^{5)}$ があるが, 空洞部の 大きさを実験変数として行った研究はいままでに行われていない。

本研究では, 空洞部の大きさを主要な実験変数とした柱の一定軸 力下の曲げせん断実験を行い, 軸力と曲げせん断力を受ける柱の耐 力・変形性能についての基礎的性状の把握を行ったものである。ま た文献 ${ }^{21}{ }^{3}$ で作成した拘束効果を考慮した軸圧維耐力式の妥当性 を実験結果と比較することにより検討する。

\section{2. 実験概要}

\section{1 試験体概要}

表 -1 に試験体の割付けを示す。実験变数㹥鋼管断面形状·空洞 率 (定義は表 -1 脚注に示す). 径 (幅) 厚比・軸力比とした。鋼管断 面形状は円形 $(\bigcirc-216.3 \mathrm{~mm}, \mathrm{STK} 400)$ と角形 $(\square-200 \times 200 \mathrm{~mm}$,

STKR400) とし，市販の冷間成形材を使用し，熱処理は行っていな い。空洞率 HRa は 0,10,20,30,50\% とした。冈形龬管の径厚比 D/t は 26,48 (板厚 $\mathrm{t}=8.2,4.5 \mathrm{~mm}$ ), 角形鋼管の幅厚比 $\mathrm{B} / \mathrm{t}$ は $17,33(\mathrm{t}=12,6 \mathrm{~mm}$ ), 軸力比 N/No は角形試験体の場合 0.3 , 円形試験体の場合 0.4 (ただ し $\mathrm{D} / \mathrm{t}=48, \mathrm{HRa}=50 \%$ の場合 $\mathrm{N} / \mathrm{No}=0.3)$ とし, 高軸力の試験体も円形 と角形で 2 体ずつ用意した ( 円形試験体の場合 $\mathrm{D} / \mathrm{t}=48, \mathrm{HRa}=0,20 \%$ で $\mathrm{N} / \mathrm{No}=0.6$, 角形試験体の場合 $\mathrm{B} / \mathrm{t}=33, \mathrm{HRa}=0,20 \%$ で $\mathrm{N} / \mathrm{No}=0.5$ ）。

\footnotetext{
本諭文の一部は1995年度日本建築学会大会 ${ }^{18)}$ で発表している。

* 前田建設工業秼特殊構造部

九州大学大学院 博士後期課程・工修

** 九州大学工学部 教授. 工博

*** 前田建設工業侏特殊構造部
}

Advanced Structural Engineering Maeda Corporation

Graduate School of Engineering, Kyushu Univ., M. Eng.

Prof., Faculty of Engineering, Kyushu Univ., Dr. Eng.

Advanced Structural Engineering Maeda Corporation 
また，充填コンクリートの圧縮強度 $(\mathrm{Fc}=98.1 \mathrm{MPa})$, せん断スパン 比 $(\mathrm{a} / \mathrm{D}, \mathrm{a} / \mathrm{B}=3.0)$ は一定とした。なお試験体名称の定義は表 -6 脚注 に示す。図 - 1 に試験体の形状を示す。試験体は試験体の上下に取 り付けたスタブ部を介して逆対称曲げモーメントが加えられるよう にした両端固定の試験体である。

表 -2 に鎆管の機械的性質を，また表 -3 にコンクリートの調合を 示す。コンクリート強度は JS A 1136 の遠心力締め固めコンクリ 一トの圧縮強度試験方法より算定し，材令は試験体と同一とし円形 試験体の場合 82-93 日，角形試験体の場合 97-112 日である。

\section{2 試験体の製作}

試験体の製作方法については，試験体のコンクリート充填は，目 標の空洞率とコンクリート比重から求めたコンクリート量を鋼管に 投入した後，遠心力成形機により締め固め，その後蒸気養生を行っ た。遠心成形は表 -4 に示す初速・中速・高速の 3 段階の遠心力を所 定の時間かけた。また蒸気養生㹥 -5 に示す前置き・昇温・温度保 持·自然冷却の 4 工程を 2 サイクル施した。なおコンクリート供試 体の遠心成形方法と養生方法は試験体と同一とした。

なお空洞率 $0 \%$ の試験体は, 空洞率 $10 \%$ 程度の試験体を製作後 (蒸気羡生まで終了後), 空洞部に高強度無収維モルタル(商品名: デンカタスコンタイプU) を充填した。

\section{3 実験方法}

実験は図 -2に示す (財) 日本建築総合試験所所有の建研式構造物 試験機を用い，試験体を上下支持部に固定し，油圧ジャッキにより 試験体の軸方向に所定の一定軸力を載荷しながら, 押し引き型油圧

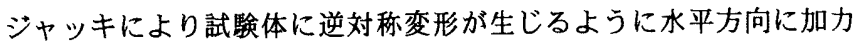
し，正負繰り返し加力による曲げせん断実験とした。水平方向の加 カスケジュールは図 -3に示すように, 正加力・負加力を 1 サイク ルとして, 部材角 $0.5 \%$ を単位に变位振幅を增加させ $0.5,1.5,2.5 \%$ で各 1 サイクル，1.0,2.0,3.0,4.0\%で各 2サイクル，それ以降は $1 \%$ を単位に変位振幅を增加させ 1 サイクル行う漸增変位振幅とした。 なお, 最終加力は試験体の破壊状況に応じて調整した。

測定項目は水平荷重·試験体各部の变位・鋼管表面のひずみ度と した。図 -1 中に変位計测位置とひずみ度測定位置を示す。変位测 定項目は部材角・軸方向変形量・材端部回転角である。ひずみ度の 測定は鋼管フランジ部 (加力方向と直交する面) とウェブ部 (加力 方向と平行な面)について行った。

\section{3. 実倹結果および考察}

\section{1 実験経過および何重一変形関係}

図 -4に円形試験体の，図 -5に角形式験体の荷重 - 变形関保 (た だし部材角 $\mathrm{R}=3 \%$ まで) を示す。柱せん断力 $\mathrm{Q}$ は, 軸力による装 置の摩擦力 (軸力の $0.2 \%$ 程度) を差し引いた值とした。図中には 䤡管に貼り付けたひずみゲージによる鋼管の降伏時 (降伏ひずみ $\varepsilon \mathrm{y}=\mathrm{s} \sigma \mathrm{y} / \mathrm{E}$ に達した時点と定義する) ( (フランジ降伏 FY, ウエ ブ降伏 WY)，目視により確認した鋼管の局部座屈発生時をく(う ランジ座屈 $\mathrm{FB}$, ウェプ座屈 $\mathrm{WB})$, 最大耐力を $\mathrm{O}(\mathrm{Qmax})$ で示してあ る。また図中には軸力による付加曲げモーメントを差し引いた，材 料強度より求めた一般化累加強度 ${ }^{6)}(\mathrm{cru}=1.0)$ の計算值を点線で示 し，軸力により柱に生じるせん断力を一点鎖線で示してある。
表 -1 試験体の割付

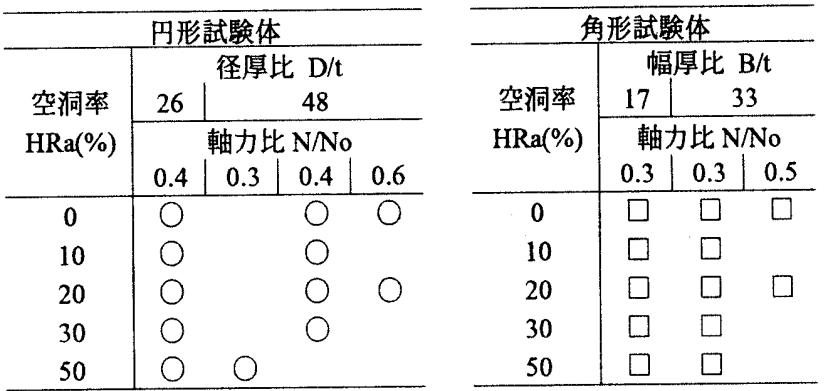

$\mathrm{O}$ :円形断面, $\square$ :角形断面

空洞率:鋼管にコンクリートを充填して中実断面としたコンクリート と鋼管の断面積の和に対する空洞部の断面積の割合

$\mathrm{N}:$ 載荷軸力, $\mathrm{No}=\mathrm{sA} \cdot \mathrm{s} \sigma \mathrm{y}+\mathrm{cA} \cdot \mathrm{c} \sigma \mathrm{B}$
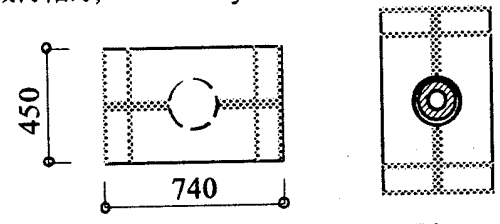

下照性 3 蚰,

$r$ 望姓 2 蚰,

十㗆性 2 航ゲージ
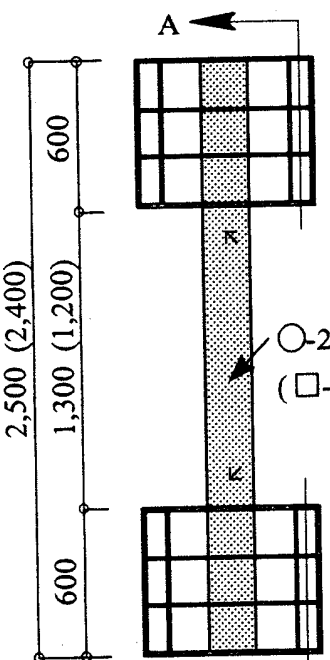

B-B'sec.
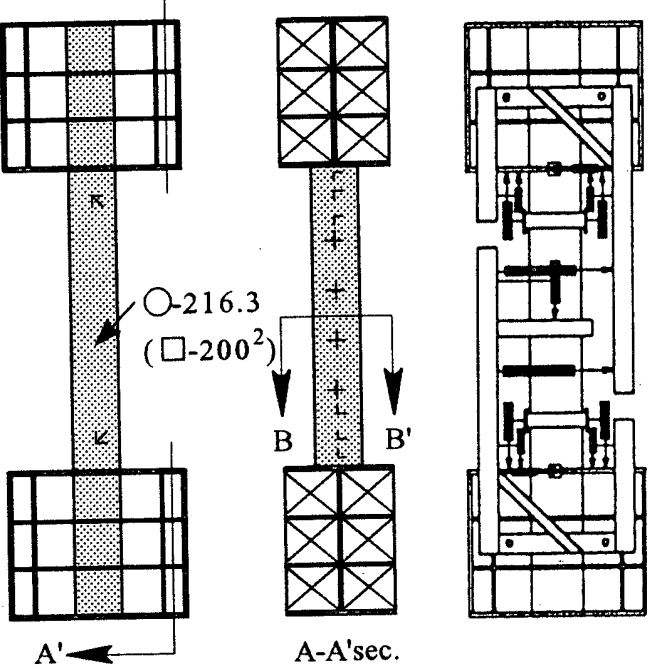

A-A'sec.

Elevation

図 -1 試跧体の形状および計測の概要

表 -2 鋼管の機械的性質

\begin{tabular}{|c|c|c|c|c|c|c|c|c|}
\hline $\begin{array}{l}\text { 鋮管 } \\
\text { 種類 } \\
\end{array}$ & 材質 & $\begin{array}{l}\text { 公称 } \\
\text { 板厚 } \\
(\mathrm{mm}) \\
\end{array}$ & $\begin{array}{l}\text { 実測 } \\
\text { 板厚 } \\
(\mathrm{mm}) \\
\end{array}$ & $\begin{array}{l}\text { 引張側 } \\
\text { 降伏点* } \\
(\mathrm{MPa}) \\
\end{array}$ & $\begin{array}{c}\text { 圧縮側** } \\
\text { 降伏点* } \\
\text { (MPa) }\end{array}$ & $\begin{array}{l}\text { 引張 } \\
\text { 強度 } \\
(\mathrm{MPa}) \\
\end{array}$ & $\begin{array}{l}\text { 伸び } \\
(\%)\end{array}$ & 伏比 \\
\hline \multirow[t]{3}{*}{ 円形 } & STK400 & 4.5 & 4.2 & 379 & 338 & 468 & 38 & 0.81 \\
\hline & $\prime$ & " & 4.14 & 431 & 322 & 488 & 32 & 0.88 \\
\hline & $\prime \prime$ & 8.2 & 8.05 & 563 & 510 & 614 & 29 & 0.92 \\
\hline \multirow{3}{*}{ 角形 } & STKR400 & 6.0 & 5.7 & 327 & 343 & 438 & 37 & 0.74 \\
\hline & " & $n$ & 5.71 & 369 & 381 & 497 & 35 & 0.74 \\
\hline & " & 12.0 & 11.44 & 406 & 414 & 482 & 38 & 0.84 \\
\hline
\end{tabular}

*降伏点は，0.2\%オフセット法により算定した。

**圧維側降伏点は，中空鋼管供武体の圧縮試験により得られた 応力ーひずみ関係より算出した。

表 -3 コンクリートの調合

\begin{tabular}{|c|c|c|c|c|c|}
\hline $\begin{array}{c}\mathrm{Fc} \\
(\mathrm{MPa})\end{array}$ & $\begin{array}{c}\text { 最大粗骨材 } \\
\text { (cm) }\end{array}$ & $\begin{array}{c}\text { スランプ } \\
(\mathrm{cm})\end{array}$ & $\begin{array}{c}\text { 空気量 } \\
(\%)\end{array}$ & $\begin{array}{c}\text { 水セx外比 } \\
(\%)\end{array}$ & $\begin{array}{c}\text { 細骨材率 } \\
(\%)\end{array}$ \\
\hline 98.1 & 15 & $4 \pm 2$ & $2 \pm 1$ & 27 & 35 \\
\hline \multicolumn{6}{|c|}{ 単位量 $\left(\mathrm{kg} / \mathrm{m}^{3}\right)$} \\
\hline 水 & セメント & 細骨材 & 粗骨材 & 混和材* & 混和凧** \\
\hline 126 & 470 & 635 & 1184 & 57 & 8 \\
\hline
\end{tabular}

*高強度発現用混和材, $* *$ 高性能減水剤 


\section{(1) 円形試験体}

全ての試験体は載荷に伴い鋼管のフランジ・ウェブが降伏し，フ ランジの局部座屈の発生の前後に最大耐力に達した。

高軸力以外の試験体 $(\mathrm{N} / \mathrm{N} 0=0.3,0.4)$ では軸力導入時または 1 サイ クル目の $\mathrm{R}=0.5 \%$ に鋼管のフランジが圧縮降伏するとともに $2-4$ サ イクル目 $\mathrm{R}=0.5-1.4 \%$ 時には鋼管ウエブがせん断降伏した。また 3-4 サイクル目 $\mathrm{R}=1.0-1.5 \%$ 時には鋼管フランジの局部座屈が生じるの こほぼ同時に最大耐力に達した。これ以降は鋼管のフランジの局部 座屈が顕著になり耐力低下を起こした。その後の性状は空洞率によ つて異なり, 空洞率 0\% では 8-9 サイクル目の $\mathrm{R}=2.1-3.0 \%$ 時にウェ ブの局部座屈が生じたが耐力低下は少なく， $\mathrm{R}=10 \%$ に達した時点 で実験を終了した。空洞率 10-50\%では 4-7サイクル目の 0.5-2.5\% 時にウェブの局部座屈が生じ，耐力の急激な低下と軸変形の增大が 顕著になり，軸力が保持できなくなったために実験を終了した。

高軸力の試験体では，軸力導入時に鋼管フランジが圧縮降伏した 後 1 サイクル目にウェブがせん断降伏し，2-3 サイクル目で龬管フ ランジに局部座届が生じるとほぼ同時に最大耐力に至り，それ以降 はウェブの局部座屈とともに耐力が急激に低下し実験を終了した。

\section{（2）角形試験体}

全ての試験体は鋼管のフランジ・ウェブが降伏し，フランジの局 部座届の発生の前後に最大耐力に達した。

高軸力以外の試験体 ( $\mathrm{N} / \mathrm{N} 0=0.3)$ では 1 サイクル目の $\mathrm{R}=0.5 \%$ まで に鋼管のフランジが圧縮降伏するとともに 2-4サイクル目 $\mathrm{R}=0.9-1.4 \%$ 時には鋼管ウエブがせん断降伏した。また 4-5サイクル 目 $\mathrm{R}=1.1-1.8 \%$ 時には鋼管フランジの局部座届が生じるのとほぼ同 時に最大耐力に達した。これ以降は鋼管のフランジの局部座屈が顕 著になり，耐力低下を起こした。その後の性状は空洞率によって異 なり，空洞率 0\%では 6-7 サイクル目の $\mathrm{R}=2.0-2.1 \%$ 時にウェブの局 部座屈が生じたが耐力低下は少なく $\mathrm{R}=10 \%$ に達した時点で実験を 終了した。空洞率 10-50\%では 4-6サイクル目の $\mathrm{R}=1.0-2.0 \%$ 時にウ エブの局部座屈が生じ, 耐力の急激な低下と軸変形の増大が顕著に なり，軸力が保持できなくなったために実験を終了した。

高軸力の試験体では，軸力導入時に鋼管フランジが圧縮降伏した 後 1 サイクル目にウェブがせん断降伏し，2-3 サイクル目で鋼管フ ランジに局部座屈が生じるとほぼ同時に最大耐力に至り，それ以降 はウェブの局部座屈とともに耐力が急澈に低下し実験を終了した。

\section{2 破壊性状}

円形試験体の場合，鋼管フランジおよびウェブの局部座屈の生じ た位置は，空洞率に関わらず径厚比によって異なり，径厚比 $\mathrm{D} / \mathrm{t}=26$ の場合柱端部から $0.2 \mathrm{D}$ 程度の位置で, $\mathrm{D} / \mathrm{t}=48$ の場合 $0.3 \mathrm{D}$ 程度の位置で生じていた。角形試験体の場合, 鋼管フランジおよび ウェプの局部座屈は，円形試験体と同様に空洞率に関わらず幅厚比 によって異なり，幅厚比 $\mathrm{B} / \mathrm{t}=17$ の場合，柱端部から $0.25 \mathrm{D}$ 程度の 位置で, $\mathrm{B} / \mathrm{t}=33$ の場合 $0.4 \mathrm{D}$ 程度の位置で生じていた。

また実駼終了後に試験体の鋼管部分を切断し，内部のコンクリー トの破壊状況を観察したところ，全ての試験体は鋼管の局部座屈位 置に対応してコンクリートが圧壊していた。またコンクリートに材 軸方向のひび割れが観察された。
表 -4 遠心成形

\begin{tabular}{ccccc}
\hline 速 & 度 & 遠心力 $(\mathrm{G})$ & 回転数(r.p.m.) & 時間(min.) \\
\hline 初 & 速 & 1 & 90 & 3 \\
中 & 速 & 10 & 280 & 2 \\
高 & 速 & 32 & 500 & 4 \\
\hline
\end{tabular}

表 -5 蒸気養生

\begin{tabular}{ccc}
\hline 工 程 & 項 目 & 内 容 \\
\hline 1 & 前置き & 常温で3時間以上放置 \\
2 & 其温 & $20^{\circ} \mathrm{C} / \mathrm{h}$ で $80^{\circ} \mathrm{C}$ まて蒸気加熱 \\
3 & 温度保持 & $80^{\circ} \mathrm{C}$ で3時間の温度保持 \\
4 & 自然冷却 & 常温まで自然冾却 \\
\hline
\end{tabular}

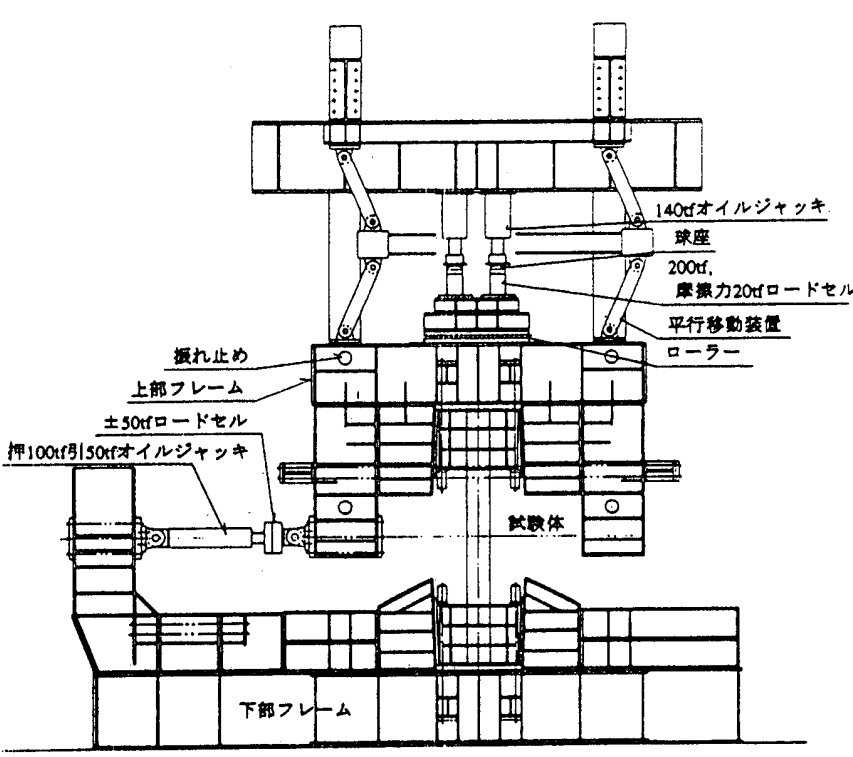

図 -2 試験装置概要

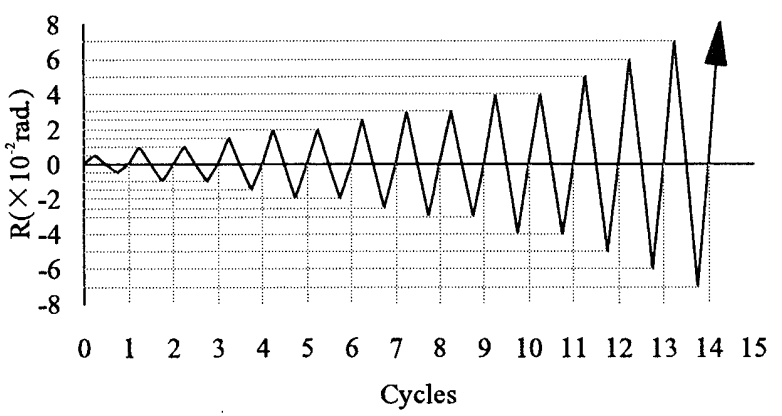

図 -3 目標加カスケシュール

\section{3 榔力}

表 -6に耐力・変形に関する実験結果の一覧を示す。SRC 規準の 一般化累加強度式 $(\mathrm{cru}=1.0)$ による終局曲げ耐力の計算值 Mcal に対 する最大耐力 $\operatorname{Mexp}($ 定義は表 -6 脚注に示す)の比を耐力上昇比と して示し，図 -6 に耐力上昇比と空洞率との関係を示す。

円形試験体の場合， $\mathrm{D} / \mathrm{t}=26, \mathrm{HRa}=50 \%$ 以外の試験体を除いて耐力 上昇比は 1.08-1.32 となり実験耐力は一般化累加強度を上回った。 耐力上昇比を実験変数ごとにみると, 径厚比による違いは見られな いが，空洞率が小さくなるにしたがいまたは軸力比が大きくなるに したがい耐力上昇比は大きくなることが判る。

角形試験体の場合，全ての試験体の耐力上昇比は1.13-1.39 とな り実験耐力は一般化累加強度を上回った。また実験変数の違いによ る影響については，幅厚比によって傾向が異なり，幅厚比が小さい 


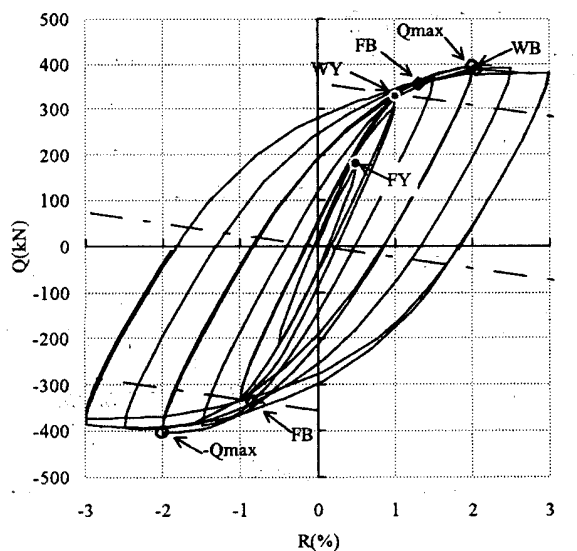

(1) $\mathrm{C} 00-2604$

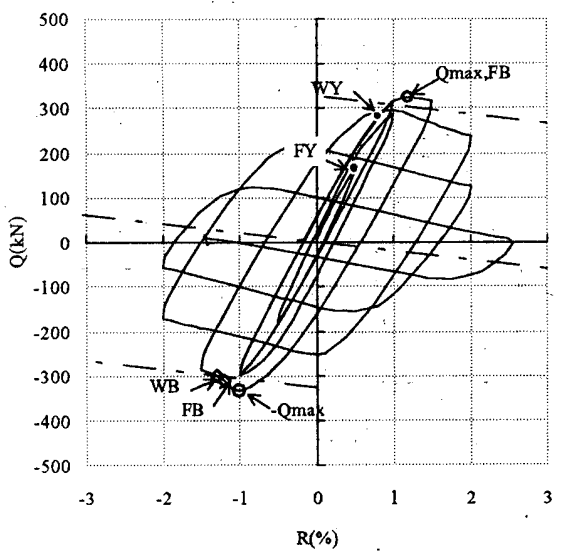

(4) $\mathrm{C} 30-2604$

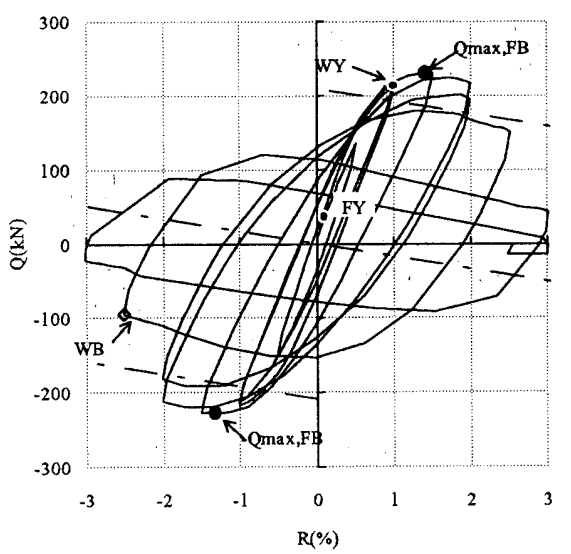

(7) $\mathrm{C} 10-4804$

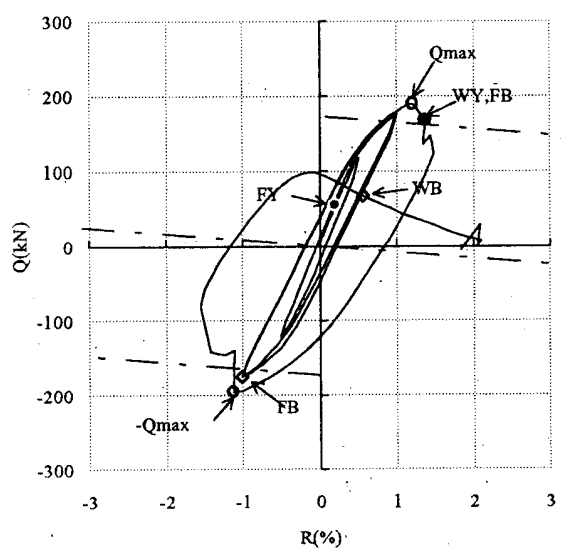

(10)C50-4803

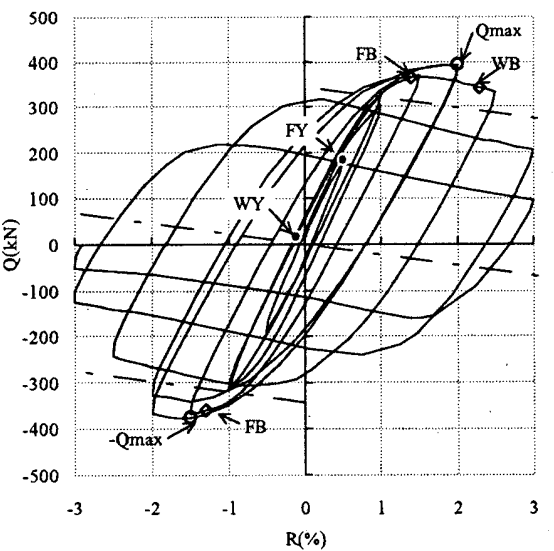

(2)C10-2604

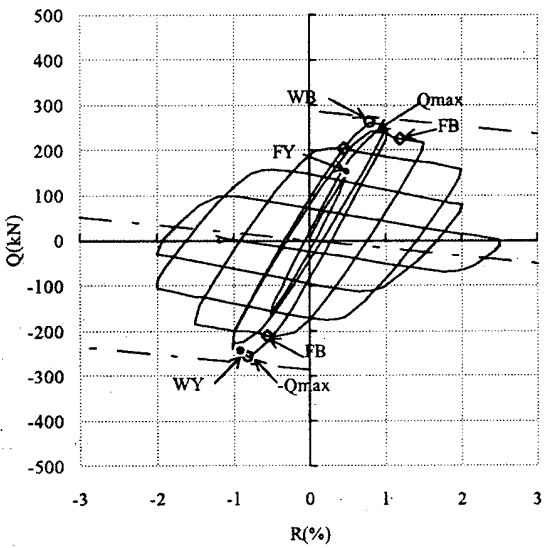

(5)C50-2604

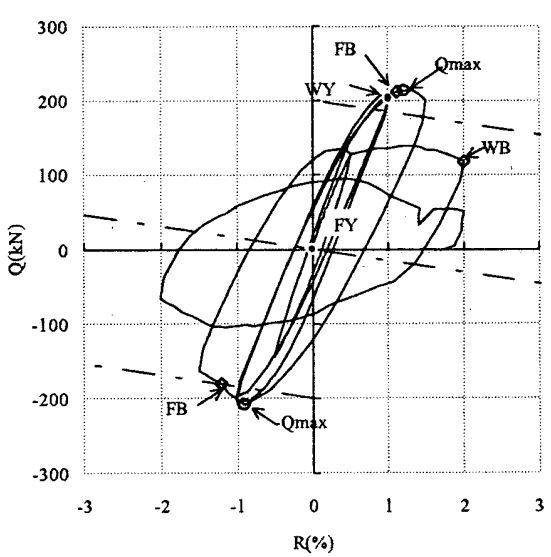

(8)C20-4804

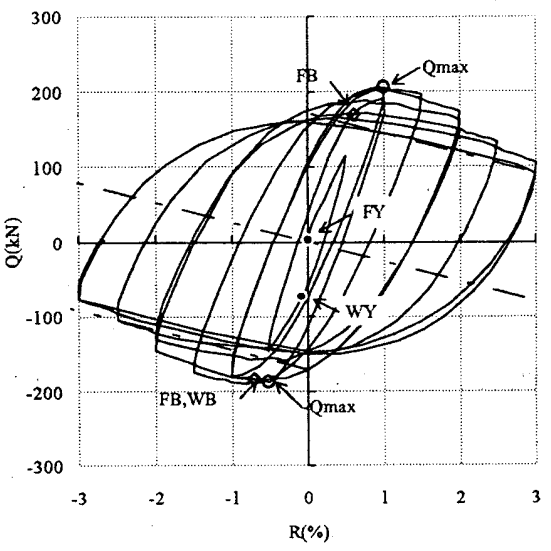

(11)C00-4806

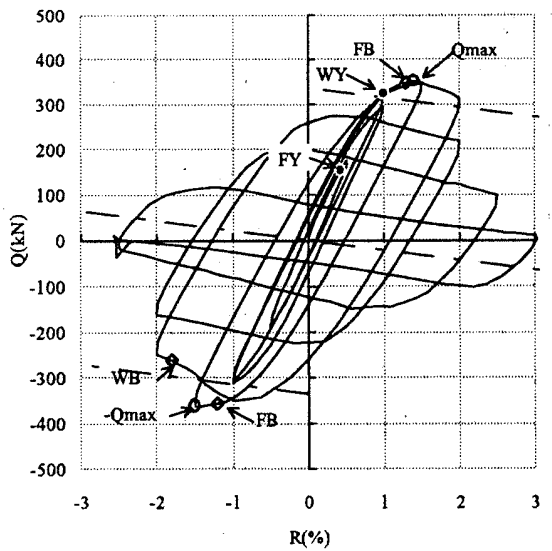

(3)C20-2604

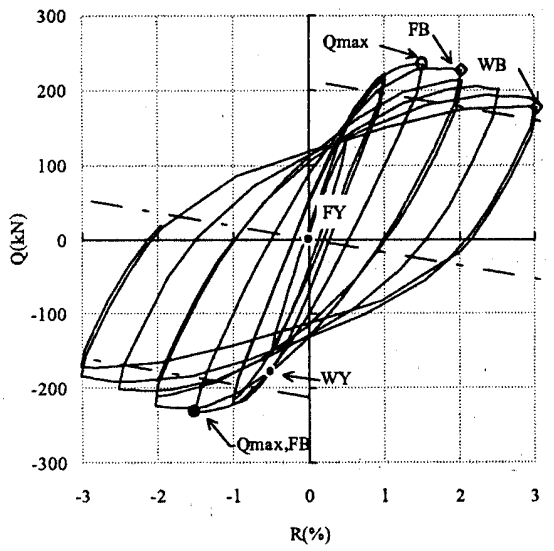

(6) $\mathrm{C} 00-4804$

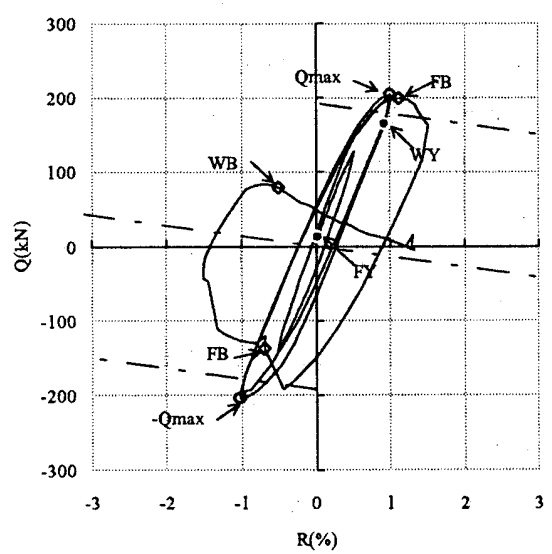

(9)C30-4804

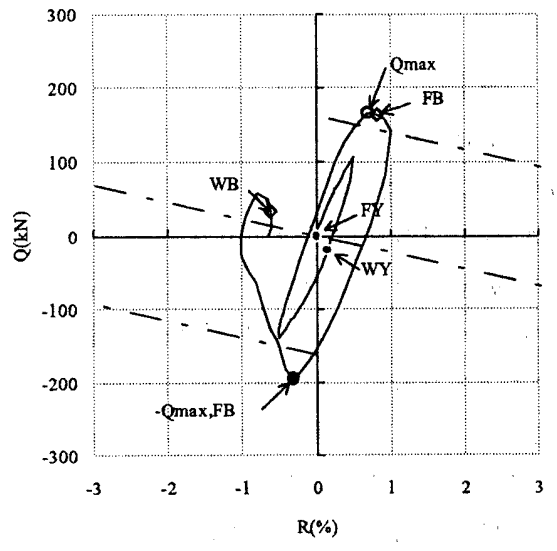

(12)C20-4806

図-4荷重一変形関係 (円形試験体) 


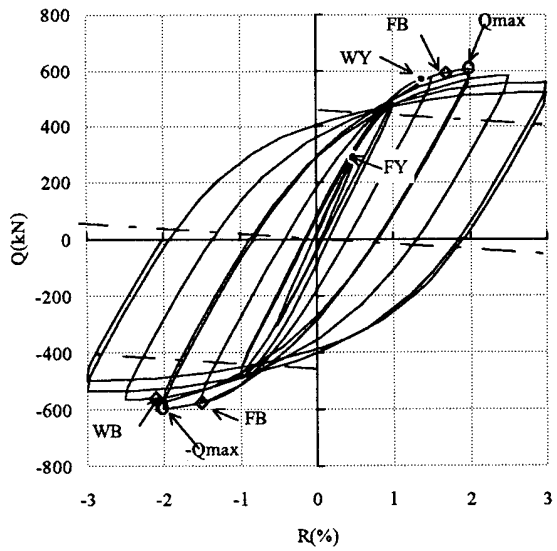

(1) $\mathrm{R} 00-1703$

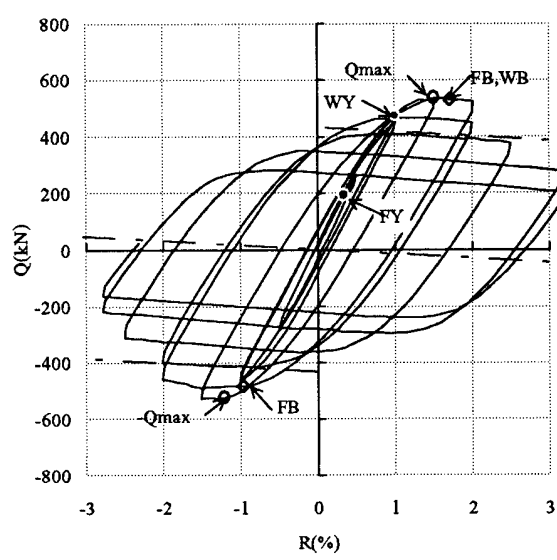

(4)R30-1703

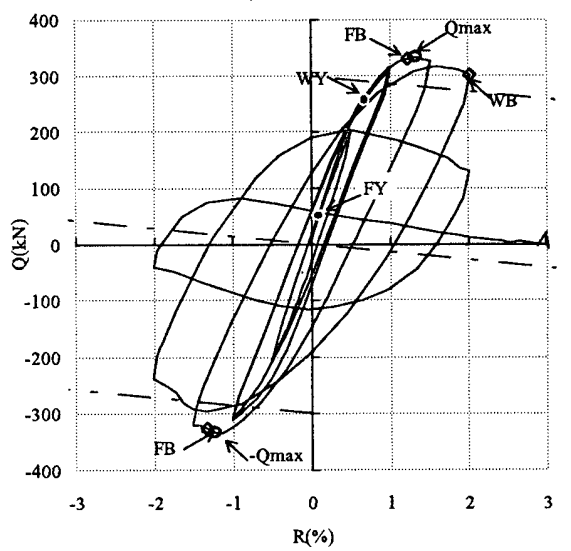

(7)R $10-3303$

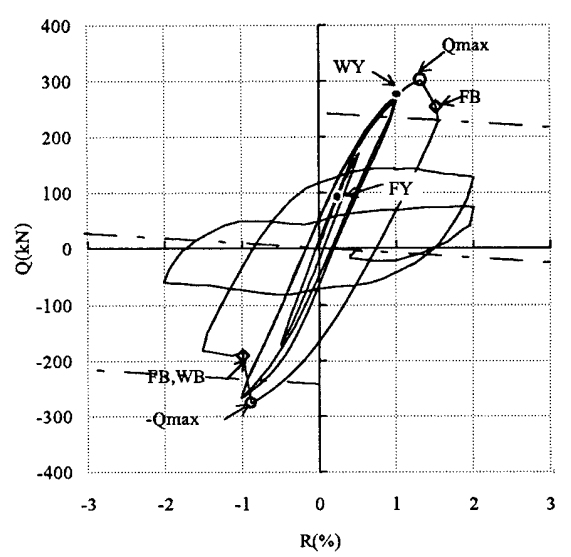

(10)R50-3303

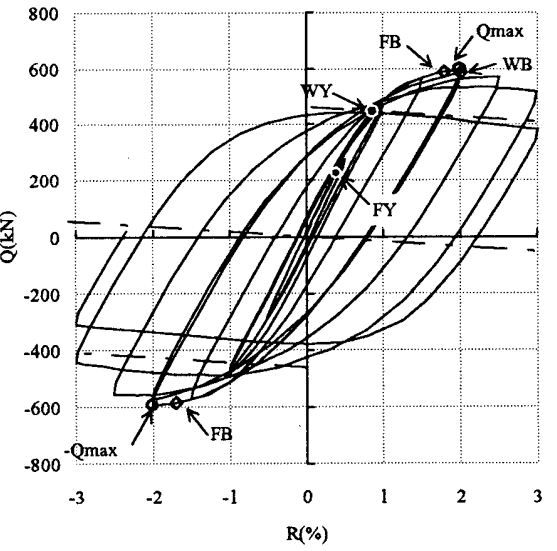

(2)R $10-1703$

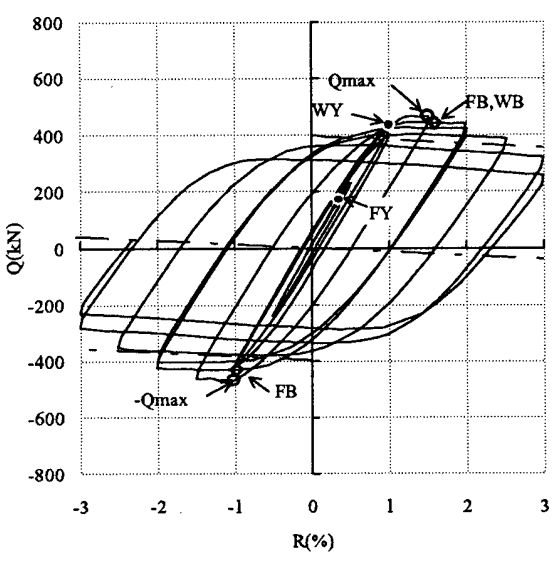

(5)R50-1703

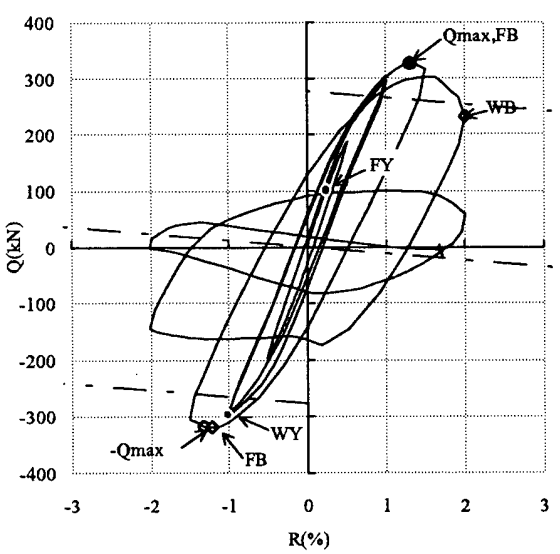

(8)R20-3303

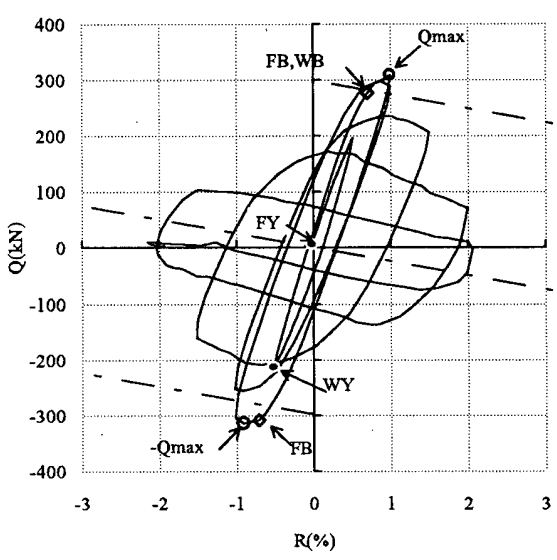

(11)R00-3305

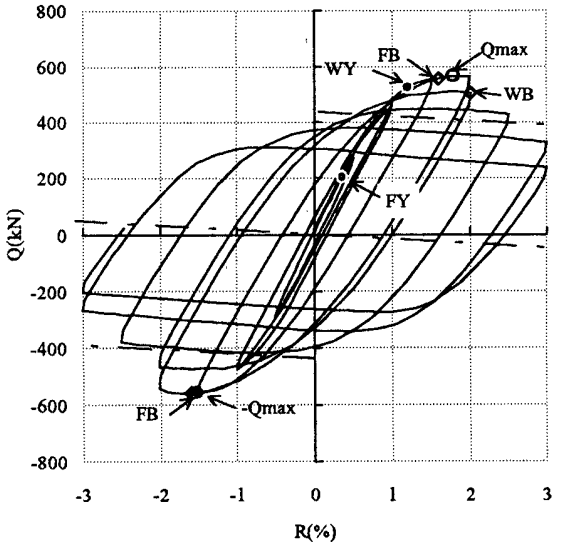

(3)R20-1703

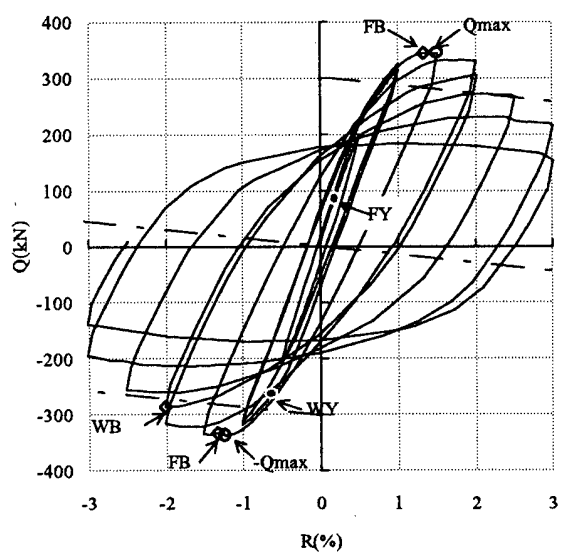

(6)R00-3303

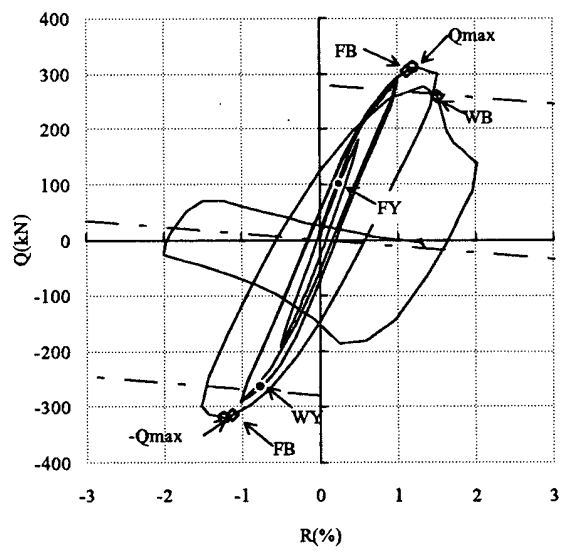

(9)R30-3303

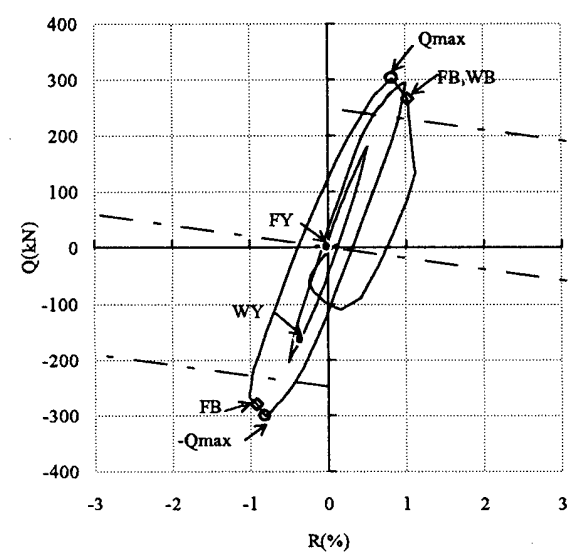

(12)R20-3305

図 -5 荷重 - 変形関係 (角形試験体) 
$\mathrm{B} / \mathrm{t}=17$ では空洞率が小さくなるにしたがい耐力上昇比は大きくなる が，幅厚比が大きい $\mathrm{B} / \mathrm{t}=33$ では空洞率が小さくなるにしたがい耐 力上昇比は小さくなることが判る。軸力比による影響は円形試験体 の傾向とは異なり，耐力上昇比に違いはあまり見られなかった。

\section{4 軸方向ひずみ}

図 -7 に高軸力以外の円形試験体について，軸方向ひすみと空洞 率との関係を径厚比ごとに示す。軸方向ひずみは, 各載荷サイクル (各 1 回目の正加力側) の最大部材角時の変位計による軸方向縮み 量を試験体長さで除した值とした。図により円形試験体の場合， $\mathrm{D} / \mathrm{t}=26$ では部材角 $1.0 \%$ まで， $\mathrm{D} / \mathrm{t}=48$ の場合は部材角 $1.5 \%$ までは 軸ひずみの增加の割合は小さいが，部材角が $2.0 \%$ になると空洞率 $20 \%$ 以上では空洞率 0-10\%の試験体に比べて急激に軸方向ひずみ が増加することが判る。空洞率 $20 \%$ 以上の試験体の軸方向ひずみ が急增するのは，材端部でコンクリートが圧壊し鋼管の座届が進展 したためであると考えられる。

\section{5 限界部材角}

柱の变形性能の評価をその一指標である限界部材角 $R u$ で検討す ることとした。限界部材角 $R u$ の定義は図 -8 に示すように軸力によ る付加曲げモーメントを除いた荷重 - 变形関係の包絡線上で最大耐 力の $95 \%$ の耐力 (耐力が安定しており最大耐力に近い耐力) に低下

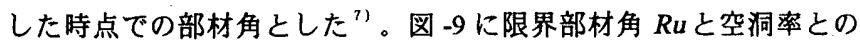
関係を示す。実験変数の違いによる限界部材角の傾向をみると，円 形試験体および角形試験体とも，空洞率または径 (幅) 厚比が大き くなるにしたがいまたは軸力比が高くなるにしたがい，限界部材角 Ruは小さくなることが判る。

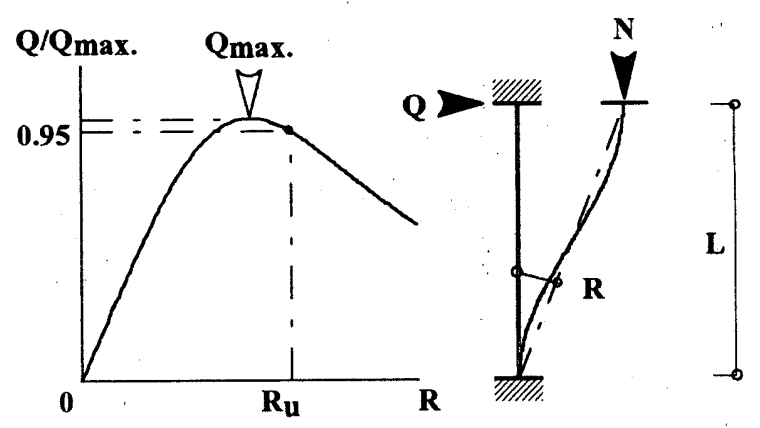

図 -8 限界部材角の定義

\section{4. 终局曲げ耐力算定式}

前節「 3.3 耐力」では実跧結果の最大曲げ耐力を，材料強度より求 めた一般化累加強度式による曲げ耐力の計算值 $\mathrm{Mcal}$ との比較を行 い，耐力上昇について検討した。ここでは拘束効果を考慮した終局 曲げ耐力式を提案し，実験結果と比較することにより提案式の妥当 性を確認する。

\section{1 格局曲け耐力の算定式}

終局曲げ酎力を図 -10 に示す応力状態を仮定した鋼管とコンクリ 一トの一般化累加強度とする。円形鋼管にはVon Mises の降伏条件, 角形鋼管の圧縮及び引張縁強度は鋼管の降伏点 $s \sigma y$ とする。充填 コンクリートの圧縮強度は拘束効果を考盧する ${ }^{2)}{ }^{31}$ 。

表 -6 実験結果一覧

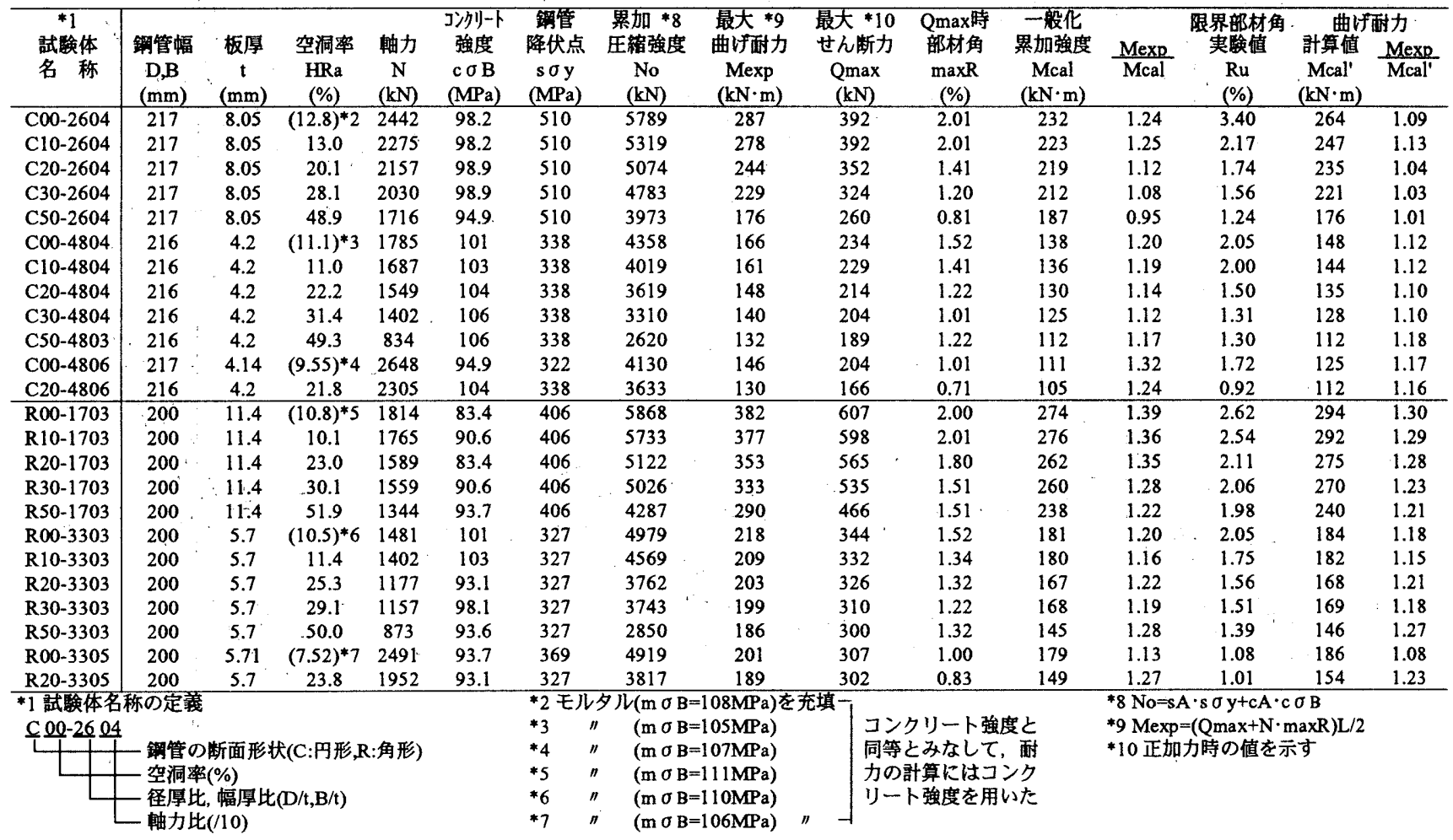




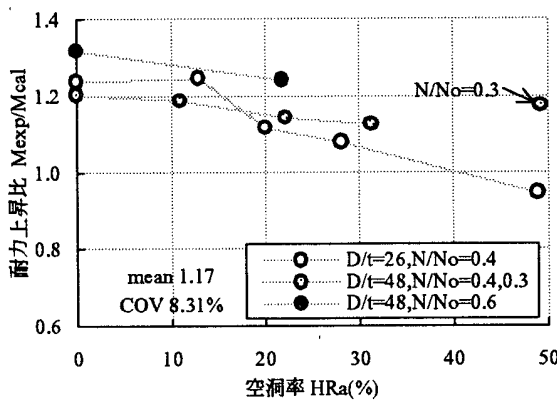

(1) 円形試験体

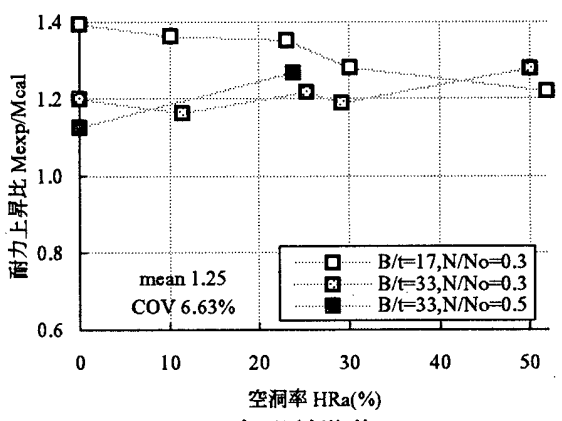

(2) 角形武験体

図 -6 耐力上昇比と空洞率との関係

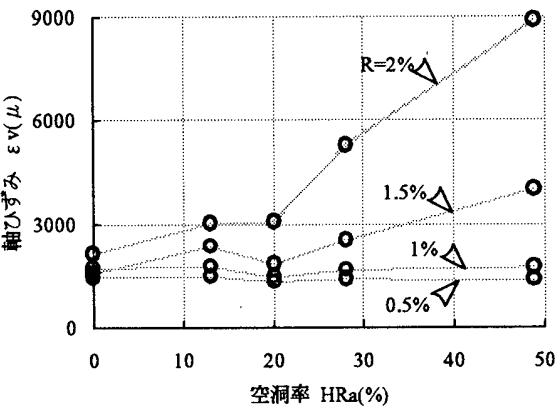

(1) 円形試験体 $(\mathrm{D} / \mathrm{t}=26, \mathrm{~N} / \mathrm{No}=0.4)$

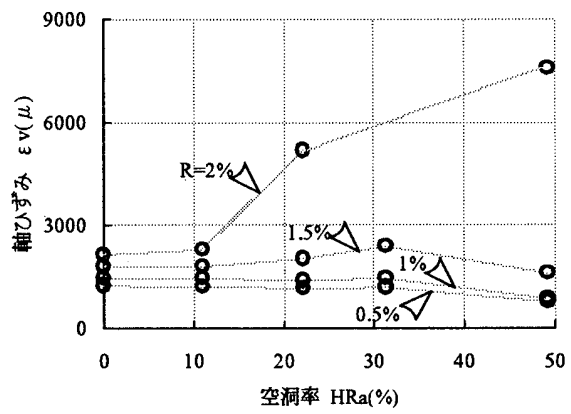

(2) 円形試験体 $(\mathrm{D} / \mathrm{t}=48, \mathrm{~N} / \mathrm{No}=0.4,0.3)$

図 -7 軸方向ひずみと空洞率との関保

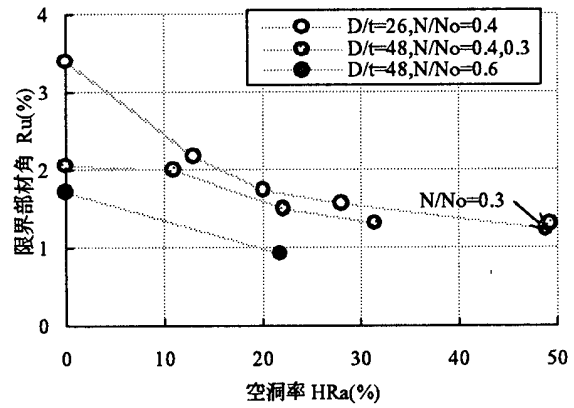

(1) 円形試験体

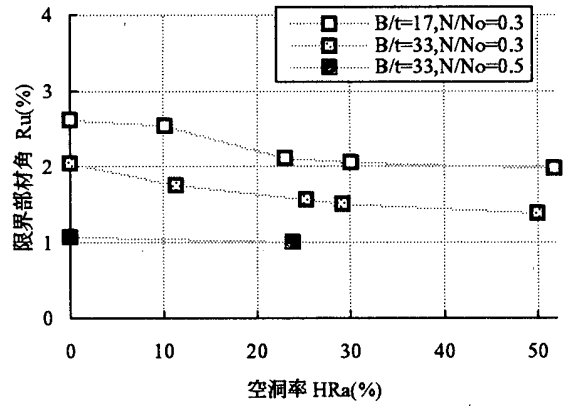

(2) 角形試験体

図 -9 限界部材角と空洞率との関係

円形断面 $(\mathrm{D} / \mathrm{t}=26-48, \mathrm{Fc}=58.8-98.1 \mathrm{MPa}, \mathrm{HRa}=0-50 \%)$

$$
\begin{gathered}
c \sigma B^{\prime}=c \sigma B+k c \times 0.21 \mathrm{~s} \sigma \text { y }\left(\frac{2 t}{D-t}\right) \\
k c=5.17-\frac{H R a}{12}
\end{gathered}
$$

角形断面 $(\mathrm{B} / \mathrm{t}=17-33, \mathrm{~F} \mathrm{c}=58.8-98.1 \mathrm{MPa}, \mathrm{HRa}=0-50 \%)$

$$
\begin{gathered}
c \sigma B^{\prime}=c \sigma B+k r \cdot s \sigma y\left(-\frac{2 t}{B-t}\right)^{2} \\
k r=4.3-\frac{3.3 H R a}{50}
\end{gathered}
$$

$k c, k r:$ 円形鋼管，角形鋼管の拘束保数，HRa:空洞率 (\%)
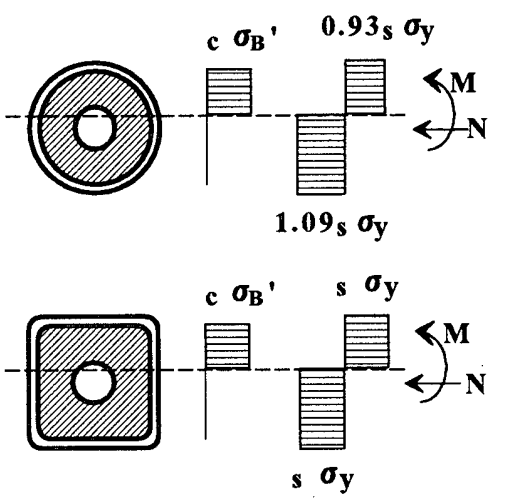

コンクリート 鋼管

図 -10 鋼管部分とコンクリート部分の応力度の分布

\section{2 実験結果と計算値との比較}

表 -6 に実験による最大耐力 Mexp と提案した拘束効果を考慮し た終局曲げ耐力式による計算値 $M \mathrm{cal}$ 'との比 $M$ exp/Mcal'を示す。 また図 - 11 には Mexp/Mcal'を空洞率ごとに示す。Mexp/Mcal'は円 形試験体の場合 1.01-1.18，角形試験体の場合 1.08-1.30 となり，実 験耐力 $M$ exp は曲げ耐力計算值 $M \mathrm{cal}$ 'を上回っていることが判る。

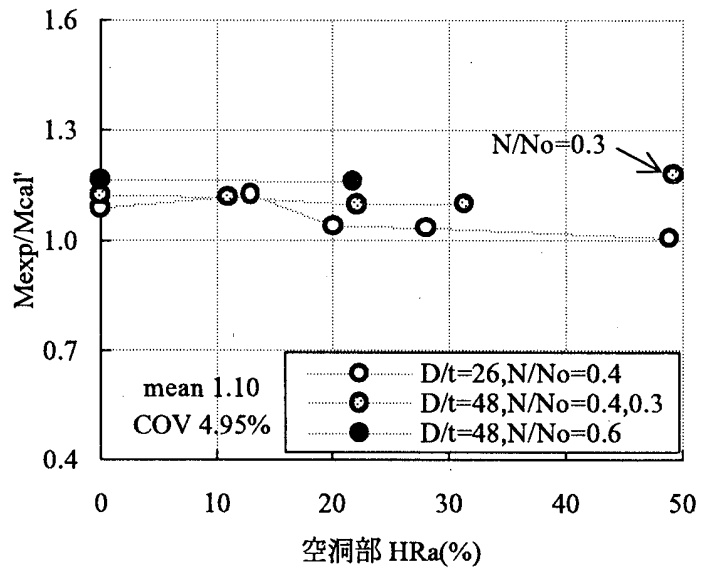

(1) 円形試験体

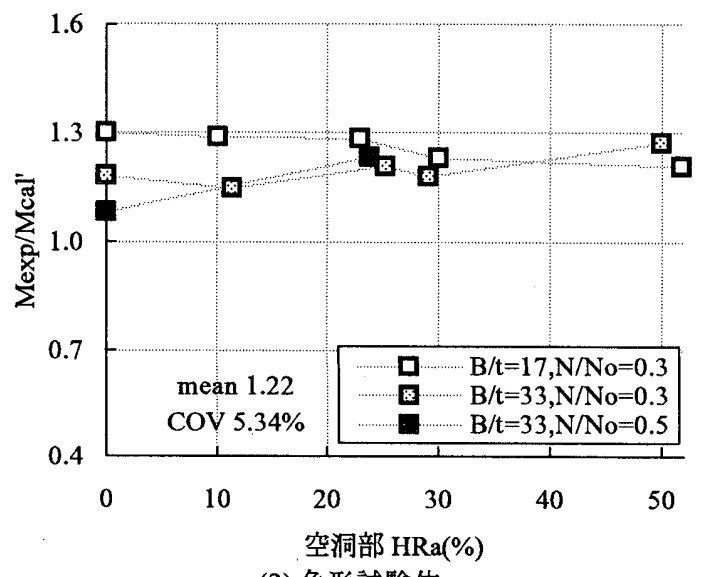

(2) 角形試験体

図-11 提案式による計算値と実験値との関係 


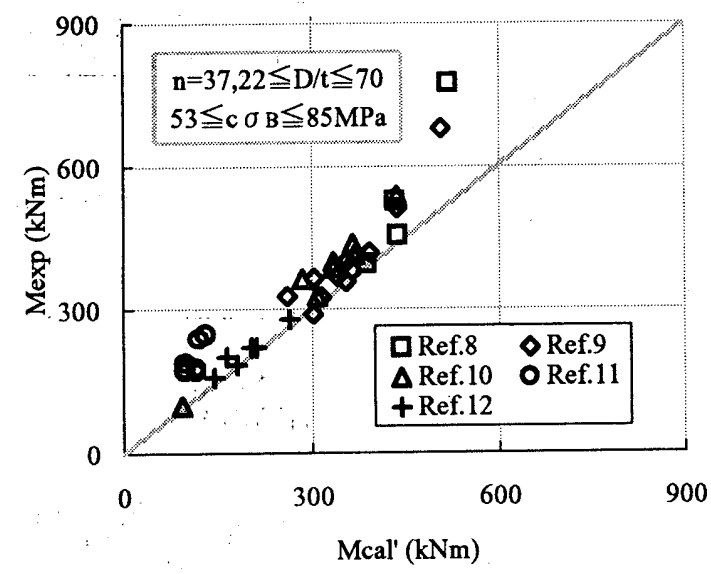

(1) 円形断面

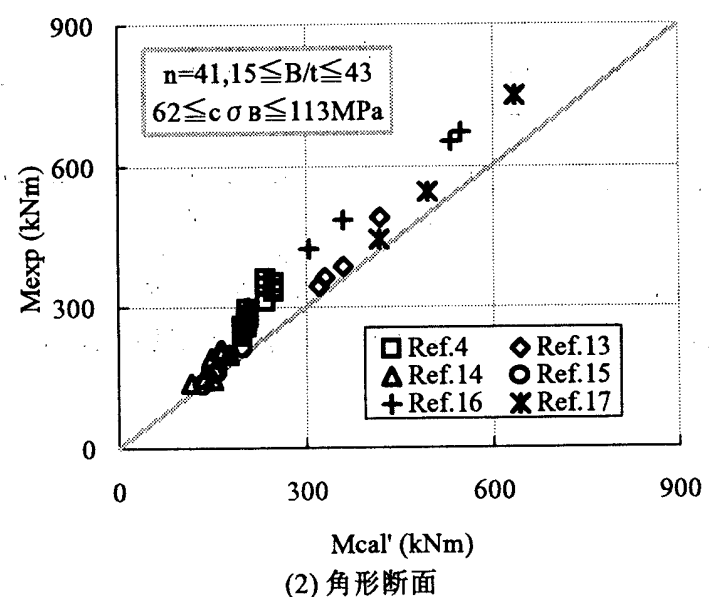

図 -12 計算檤と既往文献実験値との関係

\section{3 既往文献との比較}

図 - 12 に，空洞率 $0 \%$ に相当する既往文献 (コンクリート強度 c $\sigma B=60-100 \mathrm{MPa}$ 程度, 円形断面 ${ }^{81-121}$, 角形断面 ${ }^{41}$. 13)-17) )に 示された最大耐力と計算值の比較を示す。図により, 円形断面の場 合 $\mathrm{Mexp} / \mathrm{Mcal}=0.96-1.99$, 角形断面の場合 $\mathrm{Mexp} / \mathrm{Mcal}=0.96-1.53$ と なり，計算値は実験結果の下限を概ね示すことが判る。

\section{5. まとめ}

遠心成形コンクリート充填銅管柱の一定軸力下での曲げせん断実 験を行い，実験の範囲内で以下の結論を得た。

(1)実験結果の最大曲げ酎力 Mexpは, 一般化累加強度式による終局 曲け耐力の計算値 $M c a l$ を回った (円形試験体の場合

$M \exp / \mathrm{Mca}=1.08-1.32$ ，角形試験体の場合 $\mathrm{Mexp} / \mathrm{Mcal}=1.13-1.19)$ 。 (2)拘束効果を考慮した終局曲げ耐力の算定式を提案し，提案式によ る計算値は実験最大曲げ耐力の下限を概ね示すことを確認した。 (3)限界部材角は, 空洞率または径厚比が大きくなるほど, または軸 力比が高くなるほど小さくなる。

一定軸力下での柱の曲げせん断実験を行い, 弾塑性挙動・耐力及 び変形性能などの基礎的性状が把握できた。:また拘束効果を考慮し た曲げ耐力算定式を提案し, 実験結果と比較することで提案式の妥 当性を確認することができた。今後は本構造柱の適切な適用法を把 握する必要があると考える。
謝辞

本穆を執筆するにあたり，九州大学工学部助手津田恵吾博士に貫重な 助言を頂戴しました。試跧体製作にあたり三谷セキサン (株) 技術部 荒 木隆・渡辺正登の諸氏のご協力を得ました。また実跧実施にあたり（財） 日本建築総合詰験所構造物試跧室 益尾潔博士·尾谷透·平井義行·井 上寿也の諸氏にお世話になりました。ここに記して樑く感謝致します。

\section{考考文献}

1) 宮木·聡·松井千秋·津田恵吾 - 姆戸能夫 · 今村輝武 : 㟫心成形コンクリー 卜充填鐦管柱の軸圧縮性状，日本建築学会構造系論文集，第 482 号， pp. 121-130,1996.4.

2) 宮木 聡·松井千秋·津田恵吾 - 烟戸龍夫 · 今村輝武 : 遠心成形コンクリー 卜充填円形銅管柱の軸圧摍耐力式，日本建築学会構造系論文集，第 482 号,pp.151-160,1996.4.

3) 宮木 聡·松井千秋·津田恵吾 - 畑戸龍夫 · 今村輝武 : 透心成形コンクリー 卜充填角形鋼管柱の軸圧樎耐力式，構造工学論文集 Vol.43B,pp.581-586, 1997.3.

4) 岡本達夫 - 前野敏元 - 西澤英和 - 金寻 潔: 高強度遠心成形角形鋼管コン クリート柱の曲け耐力および変形性能に関する実験的研究，粠造工学論 文集 Vol.41B,pp.419-426,1995.3.

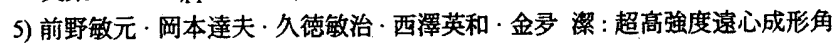
形鎆管コンクリート柱に関する実験的研究 (断面中央に中空部を有する 柱の曲げせん断実験 ), 日本建築学会大会学術講演梗概集 ,pp. 1841-1842, 1992.8.

6) 日本建築学会 : 鉄骨鉄筋コンクリート構造計算規準·同解説, 1987.6.

7) 吉野茂·渡辺朋之.今村輝武·松井千秋: 充填形鋼管コンクリート柱の 変形性能の評価式, 銚構造論文集, 第 1 巻第 2 号,pp.67-80,1994.6.

8) 上田弘樹·松谷輝雄· 中島將好·澤田誠一郎 : 充填型鋼管コンクリート柱 に関する研究 (その 3) 円形断面の軸力曲げせん断実験 - L,H シリーズ -, 日本建築学会大会学術媾演梗概集,pp.1617-1618,1989.10.

9) 上田弘樹 ·松谷輝雄 - 中島將好·吉川真次·大竹章夫 - 一戸康生 : コンク リート充填鋼管柱の超高層建物への利用についての実験的研究，その 13. 円形鋼管コンクリート柱の等曲性性状，日本建築学会大会学術講演梗概 集,pp.1067-1068,1990.10.

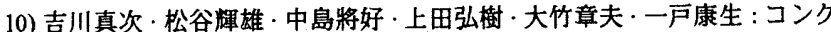
リート充填鋼管柱の超高層建物への利用についての実験的研究，その 14 円形銅管コンクリート柱の曲げせん断性状, 日本建築学会大会学術講演 梗概集 ,pp.1069-1070,1990.10.

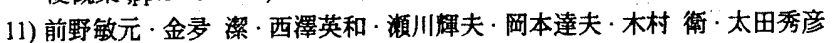
せん断スパン比の大きな充填型鋼管コンクリート柱の力学的挙動に関す る研究, その 1 コンクリート強度 Fc600 を用いた円形銅管柱について, 日本建築学会大会学術講演梗概集 ,pp.1587-1583,1994.9.

12）斉藤辟一・吉川祐三·植坂武史·古海賢二·小濱洋輔・清水孝悦 : 冷間成 形円形鋼管と高強度コンクリートを用いた充填型銅管コンクリート構造 の実験的研究，日本建築学会大会学術講演梗概集,pp:1017-1018,1996.9

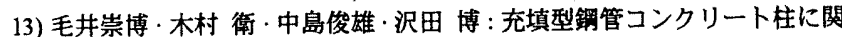
する研究 (その 6) 角形断面の軸力曲けせん断実驗 -M シリーズ -, 日本建 築学会大会学術講演梗概集,pp.1623-1624,1989.10.

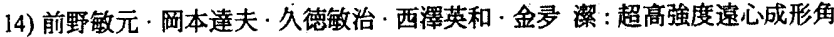
形鋼管コンクリート柱の実験的研究（鋼材種，巾圧比，軸力比に関する 検討之考察), 日本建築学会大会学術講演梗概(集,pp.1841-1842,1992.8.

15）渡边朋之·多賀 章·岩岡信一 : 鋼管コンクリート構造の開発 (その 3) 高 軸力を受ける柱部材の曲げせん断実験 , 日本建築学会大会学術講演梗概 集,pp.1819-1820,1992.8.

16) 井上貴之·福元敏之·林 信之·岡田忠義 : 高強度材料を用いたコンクリ 一ト充てん角形銅管の曲げせん断性状に関する研究, 日本建築学会大会 学術講演梗概集,pp.1599-1600,1994.9.

17) 出雲洋治·渡辺英義 - 竹崎真一 - 成原弘之 - 小林 淳 - 中村敏治 : コンクリ 一ト克填銅管柱の構造性能に関する研究 (その 2) 実験結果 (軸力曲けせ ん断実駼), 日本建築学会大会学術講演梗概集,pp.769-770,1995.8.

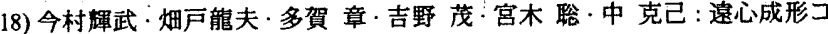
シクリート充填鋼管柱の曲け耐力および変形能力 (その 1) 実䟻概要およ び角形試験体·(その 2) 円形式験体，日本建築学会大会学術講演梗概集 pp.751-754,1995.8.

（1996年12月10日原稿受理，1997年 6 月 4 日採用決定） 